\title{
CLIMATE CHANGE IMPACTS ON AGRICLUTURE AND LIVLEIHOODS IN SIRDIBAS, MANASLU CONSERVATION AREA, GORKHA
}

\author{
Ashish Rai ${ }^{1}$ and Deepak K. Rijal ${ }^{2}$
}

\begin{abstract}
This research assesses impacts of climate change in agriculture and livelihood at Sirdibas village, Gorkha district. Apart from the review of literature, analysis of climatic and socioeconomic data, field data were collected using some selected participatory tools techniques and household survey. The analysis revealed an increased trend on mean annual temperature at the rate of $0.05^{\circ} \mathrm{C} /$ year while annual mean rainfall is increasing at the rate of 0.995 $\mathrm{mm} /$ year while the winter rainfall was in decreasing trend. Increased dry spell and rise in temperature have reduced cropping period both for summer and winter crops. An increased productivity of maize, wheat and millet over years has shown a decreasing trend in the recent years, due to intense off season rainfall followed by water logging. Shifting of farming communities to other businesses also decreased crop yield. Out-migrations have caused decreased crop yield. Along with climate change impacts change, government policy and shifting peoples' livelihood options have impacted agriculture.
\end{abstract}

Key Words: Adaptation, Crop Calendar, Crop Production, Marginal, Precipitation and Temperature

\section{INTRODUCTION}

Climate change has been the most emerging global issue and challenges of the development and environmental agenda in $21^{\text {st }}$ century. Climate change defines the temperature rise with variability and altered precipitation pattern. Temperature rise has been reported by several studies done at national and international levels. The World Bank (2007) reported that global temperature is rising by $0.06^{\circ} \mathrm{C}$ per annum. Recently World Bank (2014), in its report cited the temperature rise by $4{ }^{\circ} \mathrm{C}$ will cause a dramatic increase in the intensity and frequency of high temperature extremes throughout the world. IPPC (1995) predicted global temperature rise by $0.6 \pm 0.2^{\circ} \mathrm{C}$ by the end of $20^{\text {th }}$ century. The globally averaged combined land and ocean surface temperature data as calculated by a linear trend, show a warming of $0.85^{\circ} \mathrm{C}$ [0.65 to $1.06^{\circ} \mathrm{C}$ ] over the period 1880 to 2012, (IPCC, 2013). It is reported that temperature rise in Nepal is at $0.04-0.06^{\circ} \mathrm{C}$ and further projection are made on increasing temperature trend as $1.2^{\circ} \mathrm{C}$ by $2030,1.7^{\circ} \mathrm{C}$ by 2050 , and $3.0^{\circ} \mathrm{C}$ by 2100 in Nepal (MOE, 2010) while another study revealed a temperature rise by $0.06-$ $0.098^{\circ} \mathrm{C}$ over last 30 years (Tiwari, 2009). It has been observed in precipitation in terms of amount and duration. Baidhya et al (2007) reported erratic rainfall, unusual high intensity and less number of rainy days. As per Malla (2008), there is a marked shift of usual monsoon onset from Jestha/Ashad (June/July) to Shrawn/Bhadra (July/August) over few years since 2007/08. Other studies have also

\footnotetext{
${ }^{1}$ Researcher and Student from CDES, TU. sampang.ash1@gmail.com

${ }^{2}$ Climate Adaptation Specialist, Adaptation Group of Nepal (PVT LTD) , AGON, Lalitpur, Nepal
} 
noticed that monsoon started on $23^{\text {rd }}$ June become active only between $25^{\text {th }}$ July and $15^{\text {th }}$ October. Tiwari (2012) Reported 15-20 days delay in monsoon, high intensity and uneven distribution frequency of droughts, storms, floods, landslide, erosion, winter dry spell will increase due to climate change (NCVST, 2009). Extreme events like flood, drought, GLOFs increased (MoE/NAPA, 2010). IPCC (2007) projected the increase in intensity of rainfall in future with overall decrease as many as 15 days in number of rainy days over South Asia.

More than 74\% population is dependent on agriculture (CBS, 2011) but contribute less than $40 \%$ to the national GDP (Gurung et al., 2010). Nepal's agriculture is largely rainfed and their contribution to the GDP and food security is dependent on the characteristics of the monsoon rain. Temperature, solar radiation, precipitation, soil moisture and $\mathrm{CO}_{2}$ concentration are all important variables that determine agricultural productivity, and their relationships are not simply linear. The interaction between temperature and precipitation patterns determines the availability of soil moisture. Nepalese agriculture therefore is sensitive to climate and inadequate fund has been one of the constraints to adopt technologies so as to cope with varying climate impacts (Silwal, 2009). Any degree of change in climatic variability lead to rainfed agriculture more vulnerable putting people dependant on other natural resources and agriculture is exposed to greater risk (Downing et al., 2007). Evidence clearly shows the variability and uncertainty of atmospheric temperature and precipitation patters are increasing and communities need to understand and be capable to identify adaptation measures.

\section{OBJECTIVES}

The broader objective of this study is to assess trend of the local climate vis-a-vis potential impact on agriculture and rural livelihoods. The specific objectives are:

To analyze climatic data in order to determine the trend in climatic patterns of the study sites.

To identify key indicators to assess the impact of climate change in agriculture and livelihoods of the people.

To document crop varieties, cropping system, crop production, their cropping time and their shift in crop calendar due to climate change.

To identify adaptation measures to be adopted by the community in agriculture.

\section{METHODOLOGY}

This research methodology involves a wide range of tools and processes including the review of literature, consultation and in-house discussion and presentation to the research committee of the National Academy of Science and Technology, NAST. Data were captured through secondary and primary sources both for socio-economic and weather data from the nearest meteorological stations. Different methods and tools used for data collection and analysis are presented below.

\section{STUDY AREA}

Of the seven Village Development Committees (VDC) of the Manaslu Conservation Area (MCA) of Grokha District, Sirdibas VDC located some $160 \mathrm{~km}$ north-west of the 
District Headquarters was selected for this research. Stretched in an area of 315 $\mathrm{km}^{2}$ Sirdibas lies between $28^{\circ} 19^{\prime} 45^{\prime \prime} \mathrm{N}$ to $28^{\circ} 45^{\prime} 10^{\prime \prime} \mathrm{N}$ latitude and $84^{\circ} 29^{\prime} 00^{\prime \prime} \mathrm{E}$ to $85^{\circ} 12^{\prime} 15^{\prime \prime}$ longitude. There are 559 households with a total population of $2788: 49 \%$ male and $51 \%$ female (VDC profile, 2012). Sirdibas VDC has 17 settlements. The housing settlement spread between $1370 \mathrm{~m}$ to $2200 \mathrm{~m}$ above sea level while the highest point remains at $7893 \mathrm{~m}$ above sea level. Farmland here is fragile, marginal $^{1}$ and people own small parcels of land that are rain-fed type. Of the total VDC area only $8.89 \mathrm{~km}^{2}(2.8 \%)$ area is reported to be under agriculture while rest are barren land, grassland, forest, shrub land, rocks, river-rivulets, ponds, lakes, snow-covered area (VDC profile,2012). According to the report (DADO, 2011), the cultivable land in whole MCA region is only $1.1 \%\left(18.29 \mathrm{~km}^{2}\right)$ but other report estimates to be about $33.26 \mathrm{~km}^{2}$ (NTNC (2011). It clearly shows that only a fraction of land in whole MCA is cultivable, and all VDC of the MCA are food insecure. The study site has only $2.8 \%$ cultivable land so farming is subsistence type, insufficient and unsustainable for their living.

\section{SAMPLING AND DATA COLLECTION}

The study relies primarily on people perception; however secondary information collected from journal articles, technical papers, e-papers and newsletter were used to supplement the findings. Field survey was conducted using semi-structured questionnaire as elaborated by Fowler (1998) and Babbie (1990). Questionnaire survey was done in randomly selected 72 households (12\% sample size) given by Arkin and Colton (1966). These 72 household were selected using simple random lottery method. Participatory Research Appraisal (PRA) tools like Focus Group Discussion (FGD), Key Informants Interview (KII) and field observation were used for data collection. FGD was done with local mothers groups with pre-designed checklist. KII was done with Technician of Agriculture Service Centre, Phillim; president of Mothers Group, Phillim; VDC secretary and some nodal farmers representing old and young aged people to gather local knowledge ensuring relevant aspects of research adequately addressed. Field observation was carried out around research sites for complementary information and field verification. Climatic and crop related data was collected from DADO, MCAP, MoAD and NAST and VDC offices.

Data analysis was done collating primary and secondary data in MS-Word, Excel 2007 and SPSS 16.0. Missing rainfall and temperature data was calculated using SPSS 16.0. Regression analysis was done to see the trends in rainfall, temperature and productivity. Correlation was used to assess the relationship between productivity with time and climatic parameters (rainfall and temperature). The results thus obtained were presented pictorially in charts, diagram and graphs.

\footnotetext{
${ }^{1}$ low potential, resource poor, fragile, vulnerable or degraded land (Pratap, 1998)
} 


\section{RESULTS AND DISCUSSIONS}

The results are presented based on analysis of climatic data, productivity data supported by perception. Attempts have been made to analyze links between climatic trend and agriculture production.

\section{TEMPERATURE}

An analysis of 32 years' temperature data of station 0809, Gorkha showed that the mean temperature is in increasing at the rate of $0.05^{\circ} \mathrm{C} / \mathrm{yr}$, maximum temperature at rate $0.96^{\circ} \mathrm{C} / \mathrm{yr}$ and minimum temperature at rate $0.002^{\circ} \mathrm{C} / \mathrm{yr}$. The maximum temperature of $28.611^{\circ} \mathrm{C}$ was in the year 2010 while the minimum temperature till now recorded was in the year 2004 with $10.53^{\circ} \mathrm{C}$. Linear graph of maximum mean temperature, mean annual temperature and minimum mean temperature is shown in Figure 1 below. This increase in average temperature trend shows average of national level temperature rise. Shrestha et al (2012) reported the increasing temperature trend in Himalayan region at the rate of $0.06^{\circ} \mathrm{C} / \mathrm{yr}\left(0.04-0.09^{\circ} \mathrm{C} / \mathrm{yr}\right)$ across different ecological belt of Nepal.

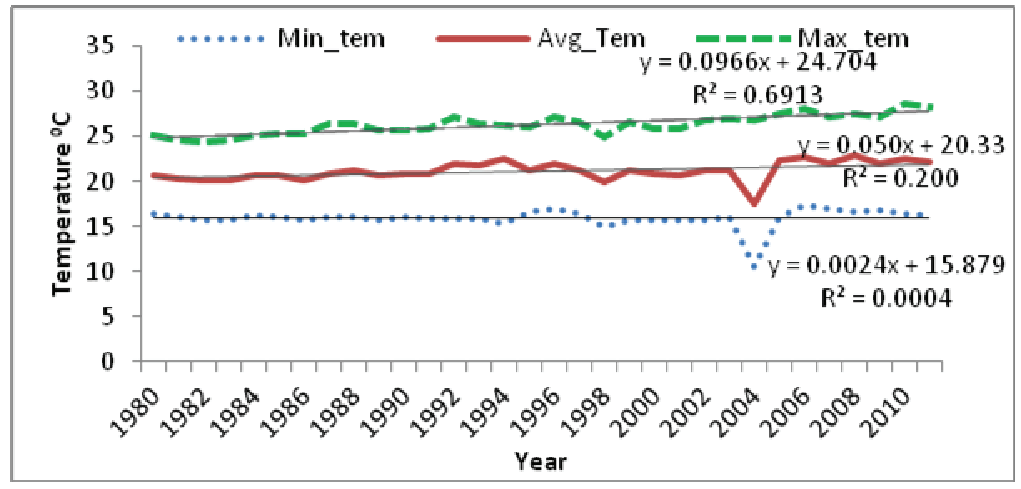

Figure 1. 32- year temperature trend of Sirdibas (DHM, 1980-2011)

\section{RAINFALL}

The analysis of 40-year metrological-data recorded at Station No. PA080171 showed that the rainfall, though irregular has been increasing at the rate of $0.995 \mathrm{~mm} / \mathrm{yr}$. Overall, the rainfall curve shows the decreasing trend of rainfall in the first 20 years period till 1991 while in the other 20 years period; rainfall is increasing with maximum irregularities. The minimum average annual rainfall recorded was in 1991 $(11.916 \mathrm{~mm})$. The maximum average annual rainfall was $167 \mathrm{~mm}$ in 2011 . The analysis showed that the maximum rainfall of $496 \mathrm{~mm}$ was recorded in 2008 in the month of July with a total rainfall of $1949 \mathrm{~mm}$ (Ashad, 2065). Linear graph of average annual rainfall is shown in Figure 2 below. 


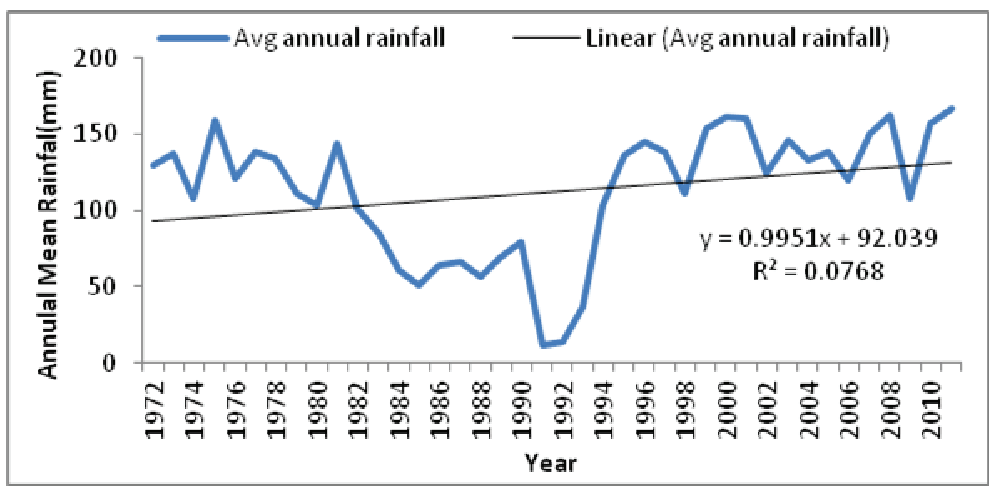

Figure 2. Annual mean rainfall of Study site (DHM, 1981-2010)

The number of days increased or decreased is not known but the intensity of rainfall has increased with irregular timing. The linear trend analysis of premonsoon, monsoon, post monsoon had been increasing at rate of $0.714 \mathrm{~mm} / \mathrm{yr}$, $2.88 \mathrm{~mm} / \mathrm{yr}$ and $0.293 \mathrm{~mm} / \mathrm{yr}$, respectively. However, the amount of winter rain found decreasing at $0.236 \mathrm{~mm} / \mathrm{yr} .72 .43 \%$ of the monsoon occurred during June September (Ashad- Bhadra). The intense rainfall caused to increase flooding and erosion affecting agriculture and livelihood (Moench, 2010). Intense rainfall in 2008 excited Lokpa khola which is said to trigger major landslide in Dewal.

\section{SNOWFALL}

Of the total, 2 settlements Anga and Nyak above $2200 \mathrm{~m}$ altitude received reduced volume of snow (2-5 inches from 9-10 inches) and also reported that the duration and timing of the snow fall were erratic. Lower Philim recorded snowfall only once in past 12 years.

\section{AGRICULTURE}

\section{Crop diversity}

In the study areas farmers have been growing a number of cereals, legumes and vegetable crop species at subsistence scales. A limited number of food crops species are traditionally grown. Some six different species are cultivated, maize, wheat and millet being the major crops. Karu before was intensely practiced along with maize, wheat, millet, barley, buckwheat but at present the karu has been refrained. Further details are presented in annex 1.

Farmers have been growing wide range of seasonal vegetables. Some 19 different Cole, Root, spice and leafy vegetables are grown in the area. Of 19 different vegetable species grown in the areas most of them were local while some introduced crop varieties were also cultivated. Potato, spinach, amaranth, pumpkin, cucumber, rayo, palungo, mustard were practiced before and the rest has been introduced recently. The list of vegetable grown in the area since 2009 is presented in annex 2 . 


\section{Ripening Period}

People are unaware of any alteration in flowering and fruiting time but have realized senescence, maturity and harvesting has shortened on some food crops. This can be the effect of increased temperature that impacts the crops phenology throughout their whole growing season. Crop harvesting period has been reduced by 10-15 days. Patel et al (2010) in their experiment of warming of soil temperature effect in wheat showed the harvesting/ripening days decreased by 12 days. The effect of temperature rise can be seen on penology of crops during early stage of growth. This indicates that the increased temperature has been affecting the crops growth. Also Robert \& Summerfield (1987) reported as temperature is known to affect the rate of development in crop growth during throughout the growing cycle. The increased temperature decreases soil temperature which is important for crop development, leaf appearance, shoot development, flowering and fruiting (Vincent \& Gregory, 1989). NARC (2005) reported that increased temperature potentially affects physiological growth of crops reducing panicle initiation, flowering, milking, and maturity by 14, 5, 6 and 14 days, respectively. Also, Koirala and Bhatta (2010) reported that harvesting period of maize, wheat and barley has been affected and reduced due to increased temperature. Annexes 3, 4, 5 and 6 show the temperature trend of given crops within their whole growing period (sowing-ripening).Table 1 shows the affects of increased temperature on senescence day of given crops.

Table 1. Increased Temperature and Decreased Senescence (whole growing period) Day

\begin{tabular}{llll}
\hline Crops & $\begin{array}{l}\text { Increased Avg. Max. } \\
\text { Tem }\left({ }^{\circ} \mathrm{C} / \mathrm{yr}\right)\end{array}$ & $\begin{array}{l}\text { Senescence Period } \\
\text { (Months) }\end{array}$ & $\begin{array}{l}\text { Decreased Senescence } \\
(\text { day })\end{array}$ \\
\hline Maize (white) & 0.096 & 8 & $10-15$ \\
Maize (yellow) & 0.097 & 7 & $10-15$ \\
Wheat & 0.078 & 9 & $5-10$ \\
Millet & 0.086 & 8 & $5-10$ \\
Barley & 0.081 & 10 & $5-10$ \\
\hline
\end{tabular}

The decreased senescence day is the number of decreased days to harvesting day counts for decreased ripening or harvesting periods of crops which mean the day counts for early ripening or harvesting of crops than usual. The temperature trend shows that within 9 and 7 months of senescence period of maize (white and yellow) there is temperature rise at a rate of $0.096^{\circ} \mathrm{C} / \mathrm{yr}$ and $0.097^{\circ} \mathrm{C} / \mathrm{yr}$, respectively which possibly reduced the senescence period on maize by 10-15 days each. Within 9 months period of senescence of wheat and millet, there is temperature rise at the rate of $0.078^{\circ} \mathrm{C} / \mathrm{yr}$ and $0.086^{\circ} \mathrm{C} / \mathrm{yr}$ which possibly reduced the senescence day by 5 10 days. Similarly, for barley there has been increase in temperature at rate of $0.081 \mathrm{C} / \mathrm{yr}$ for 10 months of senescence period that have possibly reduced senescence day by $5-10$ days. 


\section{CROP CALENDAR}

Crop calendars are important tools to track the changes in the timing or seasons referring to some season specific crop species. The key informant well briefed us on the ways that it can be analyzed to find difference on crop growing periods over time. The analysis is shown in the Figure 3 below.

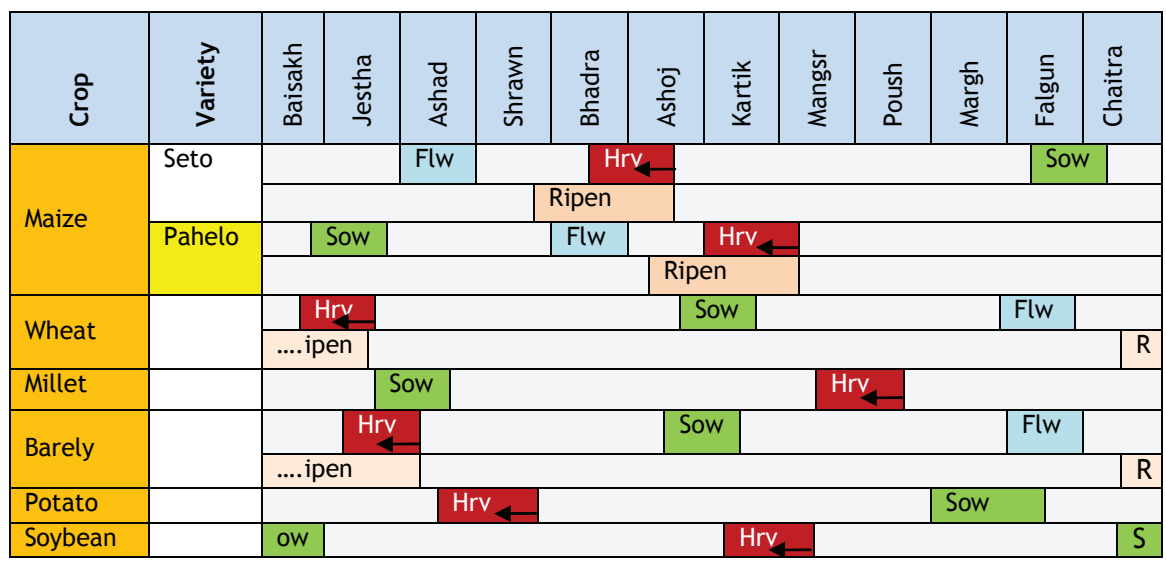

Figure 3. Crop Calendar of the Study Area

*Sow =sow, Flw = flowering, Ripen = ripening , Hrv = harvesting

Sowing period is unchanged whereas flowering/fruiting behavior is unnoticed. The cropping calendar shows change in harvesting time of the selected crops. The harvesting time for maize, wheat, barley has been shifting backward due to increasing temperature (Koirala and Bhatta, 2010). The harvesting time of maize, wheat, millet, and barley crops has been shortened by few weeks (backward arrow shows backward shifting of harvesting/ripening period). Besides, reduced harvesting (by 10-15 days) seen, alteration in sowing and flowering is unknown. A distinct shifting of sowing time can be seen in high water demanding crops (e.g., rice) but no apparent change was experienced referring to rain-fed crops here like maize, wheat, millet, barley, potato, soyabean as these crops do not require water for sowing. These species often sown with limited soil moisture and therefore shifting of sowing may be observed as indication of change in weather patterns. The crop calendar can be studied as in case of maize seto, sowing is done in Falgun/Chaitra (March/April), flowering and fruiting happens in Ashad (June/July) which starts ripening from some last week of Ashoj (July/August) and harvesting done within Bhadra/Ashoj (September/October).

\section{CROP PRODUCTION}

The respondent had different opinions about crop production trend over time which might have been due to location; $41 \%$ responded decreasing production while $28 \%$ responded increasing production, $24 \%$ responded for unchanged production and the remaining $7 \%$ respondents did not have any idea. The VDC level productivity data was/is not available so district data was used as the district data too showed decreasing production trend within last decade which agrees to the current work. 
To verify this perception district level crop yield data was analyzed to find the productivity trend.

Annexes 4, 5, 6 and 7 show the productivity of Gorkha district where the blue curve shows the overall increasing productivity trend of crops while red curve shows the decreasing productivity trend within last decade. During field survey questionnaire was made on crop productivity status in last

Table 2. Crop Production in Gorkha

\begin{tabular}{llll}
\hline Crops & Overall Production (metric & $\begin{array}{c}\text { Decreasing Production } \\
\text { ton/yr) }\end{array}$ & \multicolumn{1}{c}{$\begin{array}{c}\text { Periods decreasing } \\
\text { from in year }\end{array}$} \\
\hline Maize & 1196 & -1926 & $6 \mathrm{yr}$ \\
Wheat & 165.5 & -358.3 & $8 \mathrm{yr}$ \\
Millet & 386.1 & -627.1 & $10 \mathrm{yr}$ \\
Barley & -1.755 & -1.755 & $32 \mathrm{yr}$ \\
\hline
\end{tabular}

Table 2 shows the decreasing productivity of maize at the rate -1926 metric ton/yr when compared for over the last 6 years. Similarly, wheat and millet productivity is also decreasing at the rate -358.3 metric ton/yr and -627.1 metric ton/yr since last 8 years and 10 years, respectively. The overall productivity of barley is decreasing at the rate -1.755 metric ton/yr when estimated yield data since 32 years. Increased temperature causes depletion of soil moisture directly and indirectly through transpiration across different stages of crop growth flowering, pollination, grain filling which result on a decrease in crop yield (Khanal, 2009). So, increased temperature might have contributed to decreasing production. Craufurd et al (2010) also mentioned that the warmer temperature shortens development stages of crops growth that will probably reduce the yield of given crops. Maize (yellow) due to drought in Falgun/Chaitra (March/April) at its germinating phase might have dried out most of the seedlings. Millet due to excessive water during Ashad/Shrawn (June/July) at its initial growth stage caused root rot disease. Similarly, for wheat and barley, the dry spell from decreasing amount of winter monsoon was responsible for decreased production. Shortage of water during the dry season reduces yields over those grown with irrigation and threatens the food security of the region (Rees et al., 2004). Thus both the summer and winter crops are affected with dry spells but at varying growth stages and the extent of impact is different for different crops. Only millet which is planted during Jestha/Ashad (May/June) is affected with increased rainfall through water logging. And erratic and untimely rainfall is more frequently observed in the recent years (Gurung, 2009; Baidhya et al., 2007). Monsoon arrival during flowering, pollination not only washes away the pollen but also absence of sunlight at the time of pollination directly affects pollination in food crop species. This is one way climatic factors have been affecting crop yield in the study area.

Table 3 below shows the correlation between crops productivity and harvesting time was significant $(p<0.01)$. Correlation coefficient $(r)$ ranges between -1 to 1 
values. A positive correlation means productivity is increasing depending upon the climatic variables - timing of change in temperature and rainfall. A negative correlation means productivity in not increasing with change in climatic variables. $R^{2}$ value gives the goodness of measure of linear model. $R^{2}$ value ranges from 0 to 1 .

Table 3. Statistic of Crop Production and Time

\begin{tabular}{|c|c|c|c|c|c|c|}
\hline \multirow[b]{2}{*}{ Crops } & \multicolumn{2}{|c|}{ Overall Productivity } & & \multicolumn{3}{|c|}{ Last Decade Productivity } \\
\hline & $\mathrm{R}$ & $\mathrm{p}$-value & Remarks & $\mathrm{R}$ & $\mathrm{p}$-value & Remarks \\
\hline Maize & 0.921 & 0.001 & $\begin{array}{l}\text { Strongly } \\
\text { Correlated }\end{array}+$ & 0.174 & 0.316 & $\begin{array}{l}\text { Weakly } \\
\text { Correlated }\end{array}$ \\
\hline Wheat & 0.848 & 0.001 & $\begin{array}{l}\text { Strongly } \\
\text { Correlated }\end{array}$ & -0.576 & 0.041 & -V Correlated \\
\hline Millet & 0.707 & 0.001 & $\begin{array}{l}\text { Strongly } \\
\text { Correlated }\end{array}+$ & -0.939 & 0.001 & -V Correlated \\
\hline Barley & -0.159 & 0.384 & -V Correlatec & -0.776 & 0.004 & -V Correlated \\
\hline
\end{tabular}

\section{CROP PRODUCTIVITY AND TEMPERATURE}

Crop productivity is also affected by temperature. Increased temperatures causes heat stress affecting physiological development, maturation and finally crop yield (Khanal, 2009). Increased temperature in hills and mountains can be favorable for some crop species like maize and wheat but only in irrigated condition (Serchand, 2007). In land without irrigation, temperature might have negative impacts on physiological function. This might have caused to decreased production here. The overall crop production trend with temperature show moderate degree of positive correlation for maize while weaker degree of positive correlation for wheat, millet and barley. But the last decade trend shows the decreasing trend for all crops (see in annexes $4,5,6,7)$. This decrease might be the effect from increased heat in the lack of proper irrigation and others external factor as discussed in livelihood parts. Correlation coefficient ( $r$ ) ranges between -1 to 1 values. Table 4 below shows the correlation between crops productivity and temperature at 0.01level of significance.

Table 4. Statistic of Crop Production and Annual Mean Temperature

\begin{tabular}{llllllll}
\hline Crops & \multicolumn{2}{c}{ Overall Correlation } & \multicolumn{4}{c}{ Correlation in Last Decade } \\
& $\mathrm{R}$ & $\mathrm{p}$-Value & Remarks & $\mathrm{R}$ & $\mathrm{p}$-Value & Remarks \\
\hline Maize & 0.472 & 0.006 & $\begin{array}{l}\text { Moderately } \\
\text { correlated }\end{array}$ & $+\mathrm{v}$ & 0.506 & 0.135 & $\begin{array}{l}\text { Moderately }+\mathrm{V} \\
\text { correlated }\end{array}$ \\
Wheat & 0.180 & 0.324 & $\begin{array}{l}\text { Weakly } \\
\text { correlated }\end{array}$ & $+\mathrm{V}$ & -0.547 & 0.102 & $-\mathrm{V}$ correlated \\
Millet & 0.278 & 0.123 & $\begin{array}{l}\text { Weakly } \\
\text { correlated }\end{array}+\mathrm{v}$ & -0.548 & 0.101 & $-\mathrm{V}$ correlated \\
Barley & 0.146 & 0.427 & $\begin{array}{l}\text { Weakly } \\
\text { correlated }\end{array}$ & $+\mathrm{V}$ & -0.250 & 0.522 & $-\mathrm{V}$ correlated \\
\hline
\end{tabular}




\section{CROP PRODUCTIVIY AND RAINFALL}

Rainfall in right amount and right time can be helpful for crops to develop good physiological functions. But however, untimely erratic rainfall can be destructive to crops. Monsoon arrival during flowering time can wash away flower pollens. Untimely rainfall during pollination, flowering and increased temperature during grain filling with decreased rainfall causing dry spell have negative effects in crops yield. Decreasing pre-monsoon and winter monsoon, and increasing monsoon, postmonsoon might become destructive to crops. Summer crops like maize, millet might suffer heat stress during pre monsoon period and get negatively impacted in flowering and fruiting during excess rainfall in June/July (Ashad/Shrawn) during their flowering/fruiting time. Winter crops like wheat and barley may be affected by decreasing winter monsoon in lower settlements while in higher snowfall is beneficial for them as water source. Increased temperature and changing monsoon pattern have potential affects in crop yield in negative or positive way but negative effects will be more (Reilly et al., 2001). Overall maize and wheat productivity with rainfall shows moderate degree of positive correlation while millet shows weaker degree of positive correlation and barley shows negative correlation. But the recent trend of a decade shows all crops productivity is decreasing. This might be due to unexpected amount and timing of rainfall. Correlation coefficient $(r)$ ranges between -1to1 values. Table 5 below shows the correlation between crops productivity and rainfall $(\mathrm{p}<0.01)$.

Table 5. Statistic of Crop Production and Annual Mean Rainfall

\begin{tabular}{llllllll}
\hline Crops & \multicolumn{2}{c}{ Overall Correlation } & & \multicolumn{3}{c}{ Correlation in Last Decade } \\
& $\mathrm{R}$ & $\mathrm{p}$-Value & Remarks & $\mathrm{R}$ & $\mathrm{p}$-Value & Remarks \\
\hline Maize & 0.418 & 0.017 & $\begin{array}{l}\text { Moderately } \\
\text { correlated }\end{array}$ & 0.101 & 0.390 & $\begin{array}{l}\text { Moderately } \\
+\mathrm{v} \\
\text { correlated }\end{array}$ \\
Wheat & 0.469 & 0.007 & $\begin{array}{l}\text { Moderately }+\mathrm{v} \\
\text { correlated }\end{array}$ & -0.367 & 0.149 & $-\mathrm{V}$ correlated \\
Millet & 0.281 & 0.120 & $\begin{array}{l}\text { Weakly } \\
\text { correlated }\end{array}$ & -0.317 & 0.186 & $-\mathrm{V}$ correlated \\
Barley & -0.165 & 0.367 & -v correlated & -0.128 & 0.363 & $-\mathrm{V}$ correlated \\
\hline
\end{tabular}

\section{CLIMATIC HAZARDS}

\section{Rainfall hazards:Drought}

Drought is the resultant state of the extremely low precipitation. Shortage of water during the dry season reduces yields from irrigated crops and threatens the food security of the region (Rees et al., 2004). Chaitra and Baisakh are dry seasons and obviously agricultural lands are drier. Crops like maize and millet are affected by this dryness the maize plants get wilt and dry. However, no such event of drought in Sirdibas has been noticed till now that has caused famine. 


\section{Rainfall hazards: Water logging}

During Baisakh/Jestha in maize, water logged field from pre monsoon caused stalk rot in the injured wounds occurred during weeds cleaning. Millet is also found to be affected in the same way.

\section{Landslide}

Landslide is associated with precipitation in the presence of slope factor triggering huge land mass fall. Most of the land in Sirdibas VDC is fragile and sloppy. Agricultural land is sloppy ranging from gentle to steep and terrace less in many places of study area. Two major landslides in Dewal and Paiyu village recorded in year 2065 B.S (2008 AD). DHM meteorological records showed maximum rainfall of $496.25 \mathrm{~mm}$ in July and total rainfall of $1948.9 \mathrm{~mm}$ in this year. The intense rainfall cause flooding in local Lokpa River which supported landslide to occur. Forty to fifty ropanis of farmland, 13 houses and a mirco hydro was swept away along with 3 lives killed in Dewal landslide. In Paiyu landslide, 25-30 Ropanis of land and 11 houses were breached.

\section{Snowfall}

Snowfall occurred only in higher settlements over $2200 \mathrm{~m}$ altitude while most of the study area lies below $2200 \mathrm{~m}$ till $1370 \mathrm{~m}$. Snowfall has been seen beneficial for winter crops like wheat, barley. But sometimes snowfall during flowering time can become disastrous.

\section{TEMPERATURE HAZARDS}

\section{Senescence}

Warmer temperature shortens development stages of crops that will most probably reduce the yield of a given crop variety (Craufurd et al., 2010). The maturation period of determinate crops has been found to be reduced by a week or two weeks.

\section{Pest and disease}

The field visit reported loose smut in wheat caused from Ustilago tritici which can be threatening in near future with warmer temperature favoring for disease and pest. Vegetables were infected with aphids (lai kira) and khumle. Malla (2008) reported of development and distribution of insects and pest- diseases favored by increasing temperature, rainfall and humidity.

\section{Wilting}

Increased temperature caused wilting from evapo-transpiration process. This becomes severe in dry periods. Maize, millet suffers from wilting and even dies that reduce production. 


\section{IMPACTS IN LIVELIHOOD}

Assessment of the study area against some of the indicators in the Table 6 reveals that the farming in the area is unsustainable. Most of these indicators are climate sensitive that can be affected by temperature and precipitation. Rainfall triggered soil erosion in slope, farming without irrigation and temperature effecting physiology of crop plants are climatic effects in farming. While human acts like deforestation, out migration, food supply, increasing population also makes farming unsustainable. Because of this unsustainable farming, people livelihood is under increasing pressures. Unsustainable farming has caused the out migration among the youngsters' abroad (14\% from the sample studied). Some $10.32 \%$ people migrated outside valley (VDC profile, 2012). Subsidized food supplies and higher income from non-farm business including remittance has reduced dependency on their land for food and income. This has changed farmer attitude and behavior towards their agriculture leaving to abandon it for degradation. On the other side people who are landless, poor, marginal or who have small land parcel are affected from this degraded and unsustainable farmland.

Table 6. Indicators of Unsustainable Farming (Source: Field Score of Indicators adapted from Pratap (1998). The + sign indicates the presence of indicators in study site)

\begin{tabular}{ll}
\hline Indicators & Score \\
\hline Soil erosion rates on sloping lands & + \\
Deforestation on sloping lands & + \\
Limited size of land parcel & + \\
Steep slope cultivation & + \\
Lack of irrigation (rainfed farming) & + \\
Decreasing food grain production & + \\
Increasing population & + \\
Food grain supply by government & + \\
Out migration &
\end{tabular}

Agriculture production is thus effected by both changed livelihood and unsustainable farming side by side. Landslides victims have no choices other than become an agricultural laborer. Their production is unpredictable depending upon monsoon for irrigation. If monsoon is favorable, they have production otherwise their production is hopeless.

\section{ADAPTATION MEASURES}

Local level adaptation measures have been adopted to cope with climate change impact in agriculture. No modern technologies have been used there. Locally made plough, levelers, spades are used for preparing field and weeds clearing. Farming is subsistence in HKH region (Schroeder, $1985^{1}$ ). They use water sprinkler, water can

\footnotetext{
${ }^{1}$ Subsistence farming: rainfed, cultivation mode-human and animal, nutrient-manure, cash investmentlow, production- low and for domestic purpose, economic status- stagnant.
} 
or the tap water source for irrigating their small land parcel. Traditional random sowing pattern has been changed to systematic sowing in lines of gap $25 \mathrm{~cm}$. Organic dung has been used to fertilize their field while tobacco solution and garlic solution has been used as local insecticides. No chemical has been used as fertilizer and pesticides. Local crops have been replaced by improved varieties. Also, varieties of vegetables have been introduced since 2009. Multiple crop cycle (more than one options) with intercropping at present is being practiced. This can be taken as a climate change benefit. Before decade one cycle farming used to be practiced. Table 7 shows the adaptation measures adopted and need to be adopted by local community.

\section{Crop cycle options with intercropping}

Maize- wheat/ barley- empty

Maize/millet-

wheat/barley-empty

Maize/ bean/ soyabean-wheat/barley-empty

Maize- Oil crops- wheat

Potato-wheat-empty

Potato/maize/bean-

wheat/barley-empty

Maize- vegetable -vegetable

Maize- wheat-vegetable

Table 7. Adaptation to Climate Change Impacts in Agriculture

\begin{tabular}{|c|c|c|}
\hline Climatic Hazard & Adaptation Measures Adopted & Adaptation Measures need to Adopt \\
\hline $\begin{array}{l}\text { Landslide } \\
\text { (rainfall effect) }\end{array}$ & - Terracing farm & $\begin{array}{ll}\text { - } & \text { Proper terracing } \\
\text { - } & \text { Plantation, forestation } \\
\text { - } & \text { SALT conservation technique, } \\
\text { hedgerow }{ }^{1} \\
\text { - } \quad \text { Agroforestry }\end{array}$ \\
\hline $\begin{array}{l}\text { Drought/ Wilting } \\
\text { (temperature effect) }\end{array}$ & $\begin{array}{l}\text { - Use of Sprinkler, Water can } \\
\text { - Improved crops variety } \\
\text { - } \text { Changing cropping pattern } \\
\text { - } 2 \text { or } 3 \text { crop cycle }\end{array}$ & $\begin{array}{l}\text { - Long run irrigation system needed } \\
\text { - Water harvesting pond } \\
\text { construction }\end{array}$ \\
\hline $\begin{array}{l}\text { Disease and Pest } \\
\text { (temperature effect) }\end{array}$ & $\begin{array}{l}\text { - Garlic solution } \\
\text { - Tobacco water }\end{array}$ & $\begin{array}{l}\text { - IPM in future (in case disease is } \\
\text { threatening) }\end{array}$ \\
\hline $\begin{array}{l}\text { Water Logging } \\
\text { (rainfall effect) }\end{array}$ & $\begin{array}{l}\text { - Use of organic fertilizer increase } \\
\text { fertility and reduce water } \\
\text { logging } \\
\text { - Drainage channel }\end{array}$ & \\
\hline
\end{tabular}

\section{CONCLUSION}

Increased temperature $\left.\left(0.096^{\circ} \mathrm{C} / \mathrm{yr}-\max \right), 0.05^{\circ} \mathrm{C} / \mathrm{yr}-\mathrm{min}\right)$ and increasing rainfall $(0.995 \mathrm{~mm} / \mathrm{yr})$ indicates that the climate change is increasingly observed even at the local levels, the study shows. Pre-monsoon, monsoon, post monsoon rainfall is increasing while winter rainfall is decreasing. No change noticed in climate affected

\footnotetext{
${ }^{1}$ Nitrogen fixing plants planted in contour across slope at distance 4-6m depending in slope gradient can help reduce surface runoff by up to $30 \%$ and soil loss by up to $99 \%$ (Kiepe, 1995).
} 
sowing/flowering/ fruiting but the ripening and maturation period is found to be reduced by week or two in crops. This reduction in ripening period can indicate alteration might be in flowering/ fruiting also.Though the overall crop production trend has increased but the last few years to a decade production is decreasing. Despite improved seeds, changed cropping patterns, the intense unusual rainfall (logging) and increased temperature (wilting, dry spell) is the reason behind decreasing production. Landslide is directly affecting agriculture through sweeping away the farmland in study area. Besides, subsidized food supplies and higher income from non-farm business including remittance (increased livelihood) has reduced dependency on their land for food and income and hence production is affected. Loose smut in wheat was seen but people were unaware of the outbreak of the disease. But it is hard to link with changing climate. Climate directly impacts agriculture and livelihoods side by sides. Increased diversified options have lead farmers to abandon agriculture farming.

\section{ACKNOWLEDGEMENT}

This research is a part of NAPA extended program funded by CDKN under NCCKMC, NAST. Therefore, I am grateful to CDKN and NCCKMS, NAST. I owe my gratitude to Dinesh Raj Bhuju, PhD for his every effort in bringing this program to young researchers. I am much grateful to my respected supervisor Dipak Kumar Rijal, PhD for his most important role in supervisory and guidance throughout this research. I m equally grateful to my respected HOD Prof. Kedar Rijal, PhD (CDES) for his every support in this research work.I am much indebted to my mentor Katherine Pasteur (Katherine@Pasteur.net) for her supportive mentorship during my research. I also want to be thankful to my co-supervisor Jagannath Aryal (lecturer) of CDES for his co-supervision of this research.

I at last would like to be thankful to all those responding people and to all friends (Isha Stha Rai, Upendra K.C., Birendra Gautam, Dinesh Ghimire, and Sagun Parajuli) and my family directly indirectly involved.

\section{REFERENCE}

Babbie, E. 1990. Survey Research Methods, Belmont, Wardsworth Publishing.

Baidhya, S.K., Regmi, R.K. and Shrestha, M.L. 2007. Climate Profile and Observed Climate Change and Climate Variability in Nepal.

CBS. 2011. Population Census 2001: National Report. Central Bureau of Statistics, HMG/N Kathmandu.

Craufurd, P.Q. and Wheeler, T. R. 2009. Climate Change and the Flowering Time of Annual Crops. Journal of Experimental Botany. 60: 2529-2539.

DADO. 2011. Annual Report of District Agriculture Development, 2068/69. Gorkha.

DHM. 2012. Climatological Records of Jagat (1972-2011).

Downing, T.E., Ringius, L., Hulme, M. and Waughray, D. 2007. Adapting to Climate Change in Africa. Mitigation and Adaptation Strategies for Global Change. 2:19-40.

Fowler, F. J. 1988. Survey Research Methods, Newbury Park, Sage Publications.

Gurung, G. 2009. Impacts of Climate Change: Some Field Observations.

Gurung, A.K. and Nayava, J.L. 2010. Impact of Climate Change on Production and Productivity: A Case Study of Maize Research and Development in Nepal. Technical Paper. Journal of Agriculture and Environment. 11: 59-67.

IPCC. 1995. The Science of Climate Change. Summary of Policy Maker, Working Group 1. IPCC Second Assessment Synthesis. 
IPCC, 2013: Summary for Policymakers. In: Climate Change 2013: The Physical Science Basis. Contribution of Working Group I to the Fifth Assessment Report of the Intergovernmental Panel on Climate Change [Stocker, T.F., D. Qin, G.-K. Plattner, M. Tignor, S.K. Allen, J. Boschung, A. Nauels, Y. Xia, V. Bex and P.M. Midgley (eds.)]. Cambridge University Press, Cambridge, United Kingdom and New York, NY, USA.

Khanal, C. R. 2009. Climate Change and Organic Agriculture. Journal of Agriculture and Environment. Review Paper. 10: 102-104.

Kiepe, P. 1995. No Run-off, No Soil Loss: Soil and Water Conservation in Hedgerow Barrier Systems. Tropical Resource Management Papers no.10. Wageningen: Wageningen Agricultural University.

Koirala, M. and Bhatta, R. 2010. Communities Challenging Climate Change. Case Studies from Nepal. NEFEJ.

Malla, G. 2008. Climate Change and its Impact on Nepalese Agriculture. Journal of Agriculture and Environment. Review Paper. 9: 62-71.

MoAC, WFP. 2010. Summer Crop Nepal 2009/2010: Crop and Food Security Update. Ministry of Agriculture and Co-operatives, Government of Nepal and World Food Program.

MoAD. 2012. Statistical Information on Nepalese Agriculture. Agri-Business Promotion and Statistic Division, Ministry of Agriculture and Development, Government of Nepal.

MoE/NAPA. 2010. National Adaptation Programme of Action (NAPA) to Climate Change. Government of Nepal. Ministry of Environment, Singha Durbar, Kathmandu, Nepal.

Moench, M. 2010. Responding to Climate and other Change Process in Complex Context: Challenges Facing Development of Adaptive Policy Frameworks in Ganga Basin. Technological Forcasting and Social Change. 77:975-986.

NARC. 2005. Released and registered crop varieties in Nepal. Nepal Agricultural Research Council, Kathmandu.

NCVST. 2009. Vulnerability through the Eyes of Vulnerable: Climate Change Induced Uncertainties and Nepal's Development Predicaments. Institute for Social and Environmental Transition-Nepal (ISET-N), Nepal Climate Vulnerability Study Team (NCVST) Kathmandu.

NTNC. 2011. Management Operational Plan Conservation (2011-15) Area Management Committee, Sirdibas. Management Workplan No.1, Manaslu Conservation Area Project, Gorkha. Pp74.

Patel, R.H., Laegdsmand, M., Olesen, J.E. and Porter, J.R. 2010. Climate Change and Agriculture. Growth and Yield Response of Winter Wheat to Soil Warming and Rainfall Pattern. Journal of Agricultural Science. 148:558-562.

Pratap, T. 1998. Agricultural Sustainability Challenges in Upland Area of Semi Arid and Humid Asia. In: Proceedings of Study Meeting on Sloping Land Agriculture and Natural Resource Management. Tokyo: Asian Productivity Organization, pp. 39-84.

Rees, H.G., Holmes, M.G.R., Young, A.R. and Kansakar, S.R. 2004. Recession-based Hydrological Models for Estimating Low Flows in Ungauged Catchments in the Himalayas. Journal of Hydrology and Earth System Science. 85: 891-902

Reilly J., Tubiello, F., McCarl, B. and Melillo, J. 2001. Climate Change and Agriculture in the United States. Report. US Global Change Research Program, Chapter 13, Cambridge University Press, Cambridge.

Robert, E.H. and Summerfield, R.J. 1987. Measurement and Prediction of Flowering in Annual Crops. In: Manupulation of Flowering. London (Eds. J.G. Atherston). Pp 17-50.

Schroeder, R.F. 1985. Himalayan Subsistence Systems: Indigenous Agriculture in Rural Nepal. Journal of Mountain Research and Development. (5) 1:31-44.

Serchand et al., 2007. Climate Change and Agriculture in Nepal. July 2007. DSSAT.

Shrestha U. B., Gautam S. and Bawa K. S. 2012. Widespread Climate Change in the Himalayas and Associated Changes in Local Ecosystems. PLoS ONE 7(5): 36741. doi:10.1371/journal.pone.0036741. 
Silwal, P. 2009. Assessment of Climate Change Vulnerabilities and Adaptation Option for Sustainable Livelihood: A Case Study of Baglung Municipality, Nepal. A Project Paper Submitted for B.Sc. Institute of Forestry, TU.

Tiwari, K. R., Awasthi, K. D., Balla, M. K. and Sitaula, B. K. 2009. Local People's Perception on Climate Change, its Impact and Adaptation Practices in Himalaya to Terai Regions of Nepal. Institute of Forestry, Tribhuvan University, Pokhara,Nepal. Retrieved on Oct, 1, 2011 from URL:http://www.forestrynepal.org/publication/articles 4837.

Tiwari, K.R., Balla M.K., Pokharel, R.K. and Rayamajhi, S. 2012. Climate Change Impact, Adaptation Practices and Policy in Nepal Himalaya. In: UNU-WIDER conference on 'Climate Change and Development Policy', held in Helsinki on 28-29 September 2012.

Vincent, C.D. and Gregory, P.J. 1989. Effects of Temperature on Development and Growth of Winter Wheat Roots. Journal of Plant and Soil. 119: 87-97.

World Bank. 2007. Agriculture for Development. Overview retrieved on Dec 2, 2011 from http: //siteresources.worldbank.org/INTWDR2008/Resources/27950871192111580172WD ROver2008-ENG.pdf.

World Bank. 2014. Turn Down the $4^{\circ} \mathrm{C}$ Heat. Why a $4^{\circ} \mathrm{C}$ Warmer World Must be Avoided. A Report prepared by Potsdam Institute for Climate Impact Research and Climate Analytics for World Bank. Retrived on May 12, 2014 http: / /www-wds.worldbank.org/ 


\section{Annexes}

Annex 1. List of food crops grown in Sirdibas (field data 2012, April 27).

\begin{tabular}{llll}
\hline Common Name & Local Name & Scientific Name & Varieties \\
\hline Maize & Makai & Zea Mays & $\begin{array}{l}\text { Manakamana-1, seto ; Khumal } \\
\text { Pahelo }\end{array}$ \\
Wheat & Gahu & Triticum aestivum & Annapurna-3, R-R 21 \\
Barley & Jau & Hordeum vulgare & Local \\
Millet & Kodo & Eleusine corocana & Dalle, Pangdur \\
Soyabean & Bhatmas & Glycine max & Local \\
Buckwheat & Phapar & Fagopyrum tataricum & Local \\
Naked barley & Karu & & \\
\hline
\end{tabular}

Annex 2. List of Vegetables practiced in Sirdibas (field data 2012, April 27)

\begin{tabular}{llll}
\hline Common Name & Local Name & Scientific Name & Varieties \\
\hline Cabbage & Banda Kobi & Brassica oleraceae capitata & Green coronet/ kordio \\
Cauliflower & Phool kobi & Brassica compestris botrytis & Snow mistic, Kathmandu local \\
Raddish & Mula & Raphanus sativus & Minu early, 40 days, Tokinasi \\
Onion & Pyaj & Allium cepa & N-53 \\
Garlic & Lasun & Allium satuvum & Local \\
Bean & Simi & Phaseoulus vulgaris & Chaumase, Local round \\
Potato & Aalu & Solanum tuberosum & Potato, improved \\
Pea & Kerau & Pisum sativum & Arkel \\
Tomato & Tamatar & Lycopersicum esculutum & Srijana, Surukchha \\
Cucumber & Kakro & Cucumis sativa & Bhaktapur local \\
Mustard & Rayo & Brassica sps. & Manakamana \\
Spinach & Palungo & Spinicea oleracea & Kande \\
Carrot & Gaajar & Daucus carota sativus & New Koroda \\
Coriander & Dhaniya & Cortandrum satuvum & Kathmandu Local \\
Pumpkin & Farsi & Cucurbita pepo & Local \\
Brinjal & Vanta & Solanum melongena & Hybrid ? \\
Mustard & Tori & Brassica compestris & Local \\
Amaranth & Lattey & Amaranthus caudatus & Local \\
\hline
\end{tabular}


Annex 3. Productivity Trend of Maize

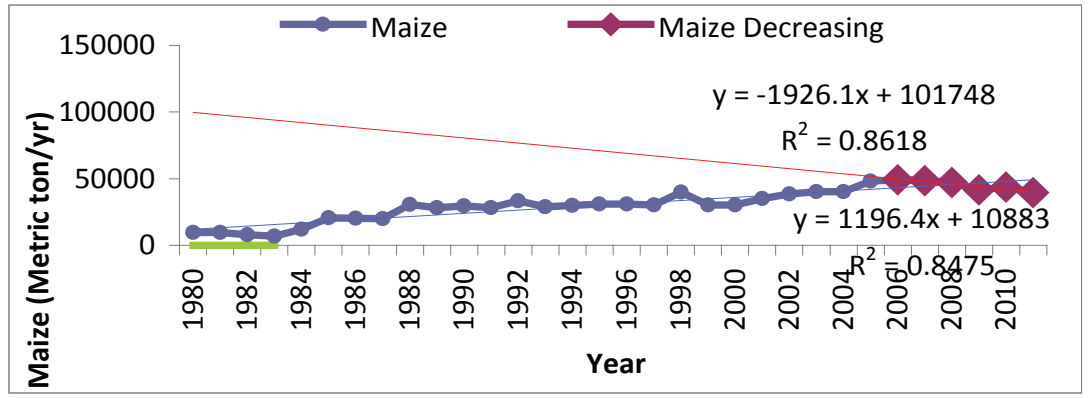

Annex 4. Productivity trend of Wheat

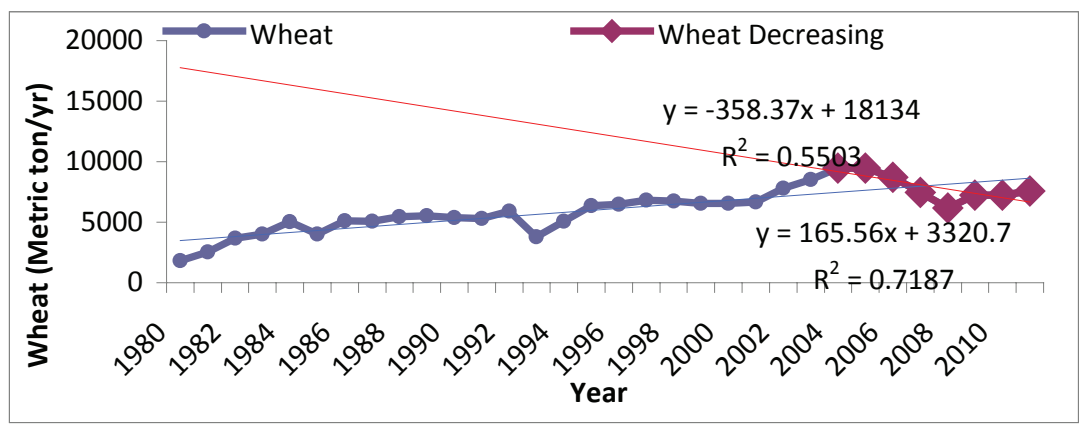

Annex 5. Productivity trend of Millet

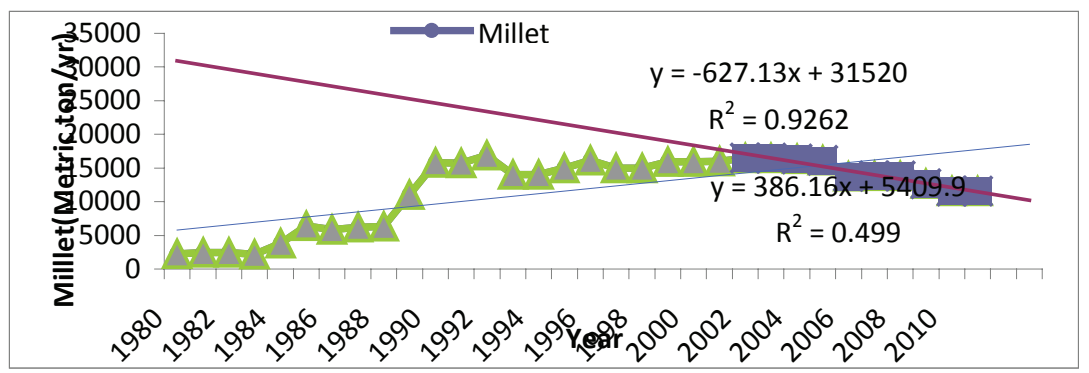

Annex 6. Productivity trend of Barley

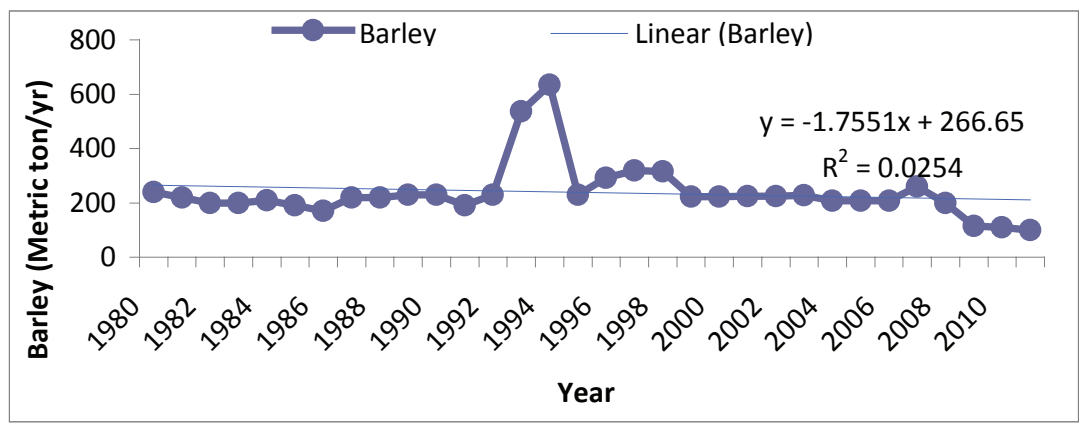

